\title{
Areas of using environmentally friendly fuel combustion technologies at TPPs of the Irkutsk Region
}

\author{
Georgiy Lachkov ${ }^{1 *}$ \\ ${ }^{1}$ Melentiev Energy Systems Institute of Siberian Branch of the Russian Academy of Sciences, Irkutsk, Russia
}

\begin{abstract}
The use of coal as the main fuel at thermal power plants in the Irkutsk Region, the significant moral and physical depreciation at many of them of the main generating equipment, mainly boiler plants, due to the long service life, determine the relevance of environmental considerations in organizing rational energy supply to regional consumers in the future. The study of the age composition, technical and environmental characteristics of the boiler equipment of thermal power plants in the region. A review of advanced technologies for burning fuel in large installations with the aim of producing thermal and electric energy. Based on an analysis of the state and environmental characteristics of thermal power plants in the Irkutsk Region, a review of advanced technologies for burning fuel in large thermal power plants, the main directions of the future use of these technologies at thermal power plants in the region are considered, taking into account their features and environmental characteristics in order to reduce harmful emissions. The list of thermal power plants recommended for conversion to natural gas burning is determined, as well as the list of thermal power plants where it is advisable to use boilers with a ring furnace or boilers with a lowtemperature vortex furnace. The potential volume of reduction of harmful emissions from the introduction of advanced technologies for fuel combustion at thermal power plants of the region is estimated.
\end{abstract}

The main commissioning of generating capacities of thermal power plants (TPP) in the Irkutsk region was carried out in the 60 s of the last century. As a result, most of the main equipment of power plants, primarily boiler equipment, is physically and morally obsolete, causing significant harm to the environment (see table). In the foreseeable future, thermal power plants in the region will require significant measures to improve their environmental performance. This is primarily relevant for power plants with the highest specific emissions of harmful substances.

Table. Annual emissions of pollutants at the HPPs of the Irkutsk energy system, $\mathrm{t}$

\begin{tabular}{|l|c|c|c|}
\hline Name & Total & $\begin{array}{c}\text { Fuel burned, t } \\
\text { of fuel } \\
\text { equivalent }\end{array}$ & $\begin{array}{c}\text { Specific } \\
\text { emissions, kg } \\
\text { / t of } \\
\text { reference fuel }\end{array}$ \\
\hline Irkutsk CHP-10 & 57678 & 1010579 & 57,1 \\
\hline $\begin{array}{l}\text { Novo-Irkutsk } \\
\text { CHP }\end{array}$ & 56349 & 1230877 & 45,8 \\
\hline Irkutsk CHP-9 & 50794 & 954455 & 53,2 \\
\hline $\begin{array}{l}\text { Novo-Ziminskaya } \\
\text { CHP }\end{array}$ & 23533 & 473301 & 49,7 \\
\hline Irkutsk CHP-11 & 21869 & 409859 & 53,4 \\
\hline Ust-Ilimsk CHP & 20048 & 483036 & 41,5 \\
\hline Irkutsk CHP-1 & 18573 & 382359 & 48,6 \\
\hline Irkutsk CHP-6 & 15863 & 589343 & 26,9 \\
\hline Irkutsk CHP-5 & 5869 & 124535 & 47,1 \\
\hline Irkutsk CHP-7 & 3515 & 196343 & 17,9 \\
\hline Irkutsk CHP-12 & 2532 & 64148 & 39,5 \\
\hline Irkutsk CHP-16 & 2120 & 91945 & 23,1 \\
\hline
\end{tabular}

\footnotetext{
*Corresponding author: g.lachkov@isem.irk.ru
}

According to [1], all operating large thermal power plants are divided into three groups:

- Boilers commissioned according to the projects approved by 31.12.1981;

- Boilers designed after 01.01.1982 and commissioned until 31.12.2000;

- Boilers commissioned from 01.01.2001.

The analysis of the composition and characteristics of the main generating equipment of the combined heat and power plants (CHP) of the region showed that the first group in the Irkutsk region includes: all boilers CHP-1, CHP-5, CHP-6 (except for boilers No. 9 and 10), CHP-9 (except for boilers No. 9-11), CHP-10, CHP-11 (except for boiler No. 9), CHP-12 (except for boiler No. 11), CHP-16, Ust-Ilimskaya CHP (except for boilers No. 6 and 7 ), boilers No. 1-4 of the Novo-Irkutsk CHP, boilers No. 1-2 of the Novo-Ziminskaya CHP, boilers No. 3-5 of the TPP-7.

For these boilers, the limiting values of technological indicators for emissions of solid particles and nitrogen oxides according to [1] are taken equal to the upper values of the range of actual indicators of specific emissions. The introduction of stricter restrictions for them is inappropriate for the following reasons: there are technical restrictions (lack of space) for the use of new emission control devices on these boilers; these boilers will be decommissioned or reconstructed in the foreseeable future due to relatively low indicators of energy efficiency, reliability, industrial safety or economic profitability. 
It has been established that the second and third groups in the Irkutsk region include: boilers No. 9 and 10 of CHP-6, boilers No. 9-11 of CHP-9, boiler No. 9 of CHP-11, boiler No. 11 of CHP-12, boilers No. 5-8 Novo-Irkutsk CHP, boilers No. 6 and 7 of the UstIlimskaya CHP, boilers No. 3 and 4 of the NovoZiminskaya CHP, boilers No. 1-2 and 6-9 of CHP-7.

For these boilers, the limiting values of technological indicators of emissions of particulate matter and nitrogen oxides according to [1] are assumed to be equal to the specific emissions that can be obtained using technologies existing in the industry.

It was revealed that at all CHPs of the Irkutsk region, the capabilities of flue gas cleaning systems are practically exhausted. Therefore, the cardinal means of ensuring environmentally friendly energy supply from TPPs in the region in the future, as noted in [2], is the use of the best available technologies (BAT) for fuel combustion.

Since all CHPs of the Irkutsk Region (with the exception of two departmental) are pulverized coal with flaring, of all the known BAT for fuel combustion in large boilers, the following are considered for use in the region: gas TPPs - taking into account the presence of the Kovykta gas condensate field (GCF) in the region; ring-fired coal-fired TPPs - taking into account the longterm positive experience of using this technology at Novo-Irkutsk CHP and coal-fired TPPs with a lowtemperature vortex furnace.

The environmental benefits of gas-fired power plants are well known. According to [1], the mass of pollutants generated during the combustion of 1 ton of standard fuel ( $\mathrm{t}$ of standard fuel) of gas is about $5 \mathrm{~kg} / \mathrm{t}$ of standard fuel, and when burning 1 ton of standard fuel. fuel oil and coal - up to $300 \mathrm{~kg} / \mathrm{t}$ of reference fuel.

Even a simple conversion of existing coal-fired power units to natural gas leads to a significant reduction in harmful emissions. For example, the conversion of the BKZ-210-140-7 boiler of the Khabarovsk CHP-1 from coal to natural gas made it possible to reduce the annual emissions of pollutants into the atmosphere by 1670 tons, including nitrogen oxide - by 109.7 tons, sulfur dioxide - by 592 , 5 tons, carbon monoxide - by 15.5 tons, solids - by 952.9 tons. The use of gas fuel also helps to reduce ash and slag and save the resource of the ash dump of the power plant. The previous seven boiler units of the Khabarovsk CHP-1 were gasified in the period from 2006 to 2016. During this time, emissions of pollutants into the atmosphere decreased by 2.5 times, the formation of ash and slag waste - by four [3].

The most efficient of the gas-fired TPPs are CCGT TPPs operating in a steam-gas cycle [4-6], the efficiency of which reaches $60-61 \%$ [4], and in the future may increase to $63-64 \%$ [5].

Coal-fired TPPs with a ring-fired furnace allow reducing nitrogen oxide emissions by $1.5-2$ times. The use of annular furnaces when creating boilers for large power units allows: to reduce the height of the boilers by $30-40 \%$; reduce their metal consumption and cost up to $10 \%$; to provide slag-free and highly economical combustion of slagging bituminous and brown coals.
The only boiler in the world power engineering practice with a unique ring-type furnace and the largest drum-type boiler in the country - the BKZ-820 boiler operates at the Novo-Irkutsk CHP [7]. Long-term experience of successful operation of the BKZ-820 boiler with an annular furnace at the Novo-Irkutsk CHP and the study of the profile of boilers for $330 \mathrm{MW}$ units firing brown and hard coal confirm the possibility of efficient use of boilers with annular furnaces both for the construction of new stations and for replacing spent large power units. with their installation in the existing cells of the main building. In this case, the power and parameters of the steam of the new block can be preserved or significantly increased [8-9].

Coal-fired TPPs with a low-temperature vortex furnace ensure stable ignition of low-grade fuels, no slagging of heating surfaces and a decrease in harmful emissions (nitrogen oxides - by $30-70 \%$, sulfur oxides by $20-50 \%$ ). Low-temperature vortex (NTV) combustion technology is a domestic development. The NTV technology is based on stepwise vortex combustion of coarsely ground fuel under conditions of multiple circulation of particles in a chamber furnace [10-11].

NTV combustion technology has been tested on a wide range of solid fuels, including brown and hard coal. Among the latest successfully implemented projects are the modernization (in 2008) of the BKZ-210 boiler at the Kirovskaya CHP-4 (the multi-fuel boiler technology has been tested) and the technical re-equipment (in 2013) of the P-49 boiler, which is part of the $500 \mathrm{MW}$ power unit at Nazarovskaya TPP.

The main application of gas technologies in the thermal power industry of the Irkutsk region is the conversion to natural gas of Novo-Ziminskaya CHP in Sayansk, CHP-12 in Cheremkhovo, CHP-11 in UsolyeSibirskoye, CHP-9 and CHP-10 in Angarsk, NovoIrkutsk CHP in Irkutsk with full-scale gasification of the region on the basis of the Kovykta gas condensate field. The choice of these CHPs for conversion to natural gas is due to their location along the route of the proposed main gas pipeline Kovykta - Sayansk - Angarsk Irkutsk.

At the same time, it seems promising to introduce a steam-gas cycle at operating CHPs with the transfer of boilers to the combustion of natural gas and the superstructure of power units with gas turbine units (GTU).

The integrated technical and economic assessment carried out at the ISEM SB RAS using the actual performance of the thermal power station of the Irkutsk region identified the zones of efficiency of existing coalfired CHPs and gas CCGT-CHPs created on their basis (see Fig.) [12]. 


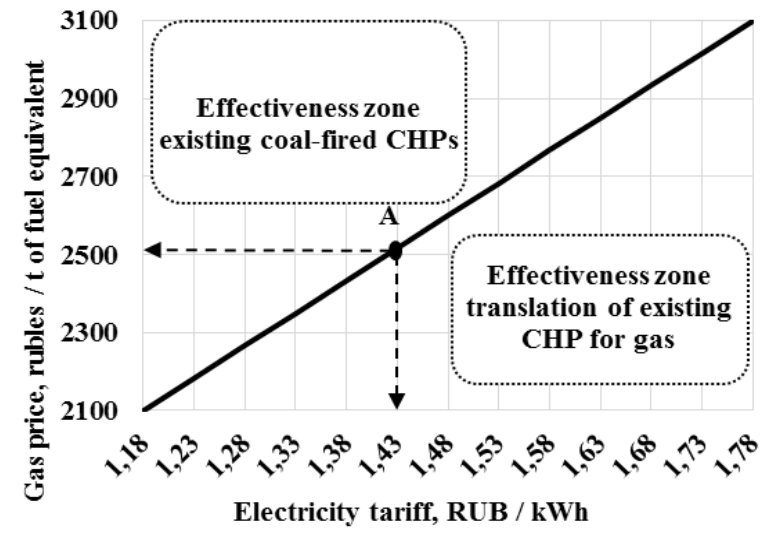

Fig. Effectiveness zones of projects for the transfer of CHPs to the combined cycle.

The constructed dependence makes it possible to choose a feasible variant of the CHP development in terms of two main external parameters - gas price and electricity tariff. So, for example, at a tariff of 1.43 rubles / $\mathrm{kW} \cdot \mathrm{h}$ and a gas price of just over 2500 rubles / tce. The options for the existing coal-fired CHP and its modernization at the CCGT-CHP are equally economical. At lower electricity tariffs, the conversion of existing coal-fired CHPs to gas seems to be ineffective, at higher tariffs - effective.

In the future, the use of gas technologies is also possible at newly constructed TPPs. So, in the Scheme and program for the development of the electric power industry of the Irkutsk region for the period 2019-2023, the commissioning of a 230 MW CCGT unit No. 1 at the gas Lenskaya TPP proposed for construction near the city of Ust-Kut is considered as additional proposals for the development of generation facilities in the region. The heat supply scheme for the city of Irkutsk for the period up to 2017 and with the prospect until 2027 as an alternative to the main variant of the development of the scheme (laying a heating main from CHP-10 in Angarsk to the Leninsky District of Irkutsk) considered the possibility of construction in different areas of the city three small CHP plants using natural gas. One of them (CCGT CHP with an electric capacity of $330 \mathrm{MW}$ and a thermal capacity of $331 \mathrm{Gcal} / \mathrm{h}$ ) can be built on the outskirts of Marat, and two others (GTU CHP with an electric capacity of $36 \mathrm{MW}$ and a thermal capacity of $357 \mathrm{Gcal} / \mathrm{h}$ and a CCGT CHP with an electric capacity of $150 \mathrm{MW}$ and thermal power $160 \mathrm{Gcal} / \mathrm{h}$ ) - in the Leninsky district.

Ring-fired boilers and boilers with low-temperature vortex furnaces can be used in the reconstruction of UstIlimskaya CHP, CHP-6 and CHP-7 in Bratsk, CHP-16 in Zheleznogorsk-Ilimsky.

Preliminary calculations show that the conversion to natural gas of Novo-Ziminskaya CHP in Sayansk, CHP12 in Cheremkhovo, CHP-11 in Usolye-Sibirskoye, CHP-9 and CHP-10 in Angarsk, The Novo-Irkutsk CHP in Irkutsk will reduce annual harmful emissions by 128 thousand tons, and the replacement of coal-fired boilers with direct flaring with coal-fired boilers with a ring furnace or low-temperature vortex furnace at UstIlimskaya CHP, CHP-6 and CHP- 7 in Bratsk, CHP-16 in Zheleznogorsk-Ilimsky will reduce annual harmful emissions by 5-12 thousand tons.

\section{Acknowledgements}

The study was carried out with the financial support of the Russian Foundation for Basic Research and the Government of the Irkutsk Region within the framework of the scientific project No. 17-48-380002 r_a.

\section{References}

1. Information and technical guide on the best available technologies "Combustion of fuel in large installations for the purpose of energy production" (ITS 38-2017). Entered into force on 01.07.2018, Moscow: Bureau of NDT, 2017.271 p.

2. G.G. Lachkov, B.G. Saneev. Ensuring environmentally friendly energy supply during the development of thermal power plants in the region // Bulletin of the Irkutsk State Technical University. 2019. No. 1. P. 115-123.

3. The eighth boiler unit of the Khabarovsk CHPP-1 was switched to gas. Available at: http://www.rushydro.ru/press/holdingnews/105015.html (12.11.2018).

4. G.G. Olkhovsky. Combined-Cycle Plants: Yesterday, Today, Tomorrow (Review) // Thermal Engineering. 2016. No. 7. P. 38-45.

5. Gulen S.C. Looking beyond air cooling fo 64 or $65 \%$ net efficiency // Gas Turbine World. JulyAug. 2014. P.33-35.

6. Trukhny A.D. Combined Cycle Plants of Power Plants. Moscow: MPEI Publishing House, 2013.648 p.

7. The Irkutskenergo company has patented the method of operation of the only boiler in Russia with an annular furnace in different modes. Available at: http://www.irkutskenergo.ru/news/3870.html (21.12.2017).

8. Serant F.A., Ustimenko B.P., Zmeikov V.N., Krol V.O. Ring furnaces of pulverized coal boilers. Alma-Ata: Nauka, 1988.168 p.

9. Serant F.A. Development and research of an annular furnace, its industrial implementation and testing on a boiler with a steam capacity of $820 \mathrm{t} /$ h. Abstract of dissertation for the degree of Doctor of Technical Sciences. Novosibirsk, $1999.58 \mathrm{p}$.

10. Rundygin Yu.A., Skuditsky V.E., Grigoriev K.A., Tokunov A.P. Modernization of boilers on the basis of low-temperature vortex technology of solid fuel combustion // Energetika: economics, technologies, ecology. 2000, no. 4. S. 19-22.

11. Rundygin Yu.A., Grigoriev K.A., Skuditsky V.E. Low-temperature vortex technology of solid fuel combustion: implementation experience, prospects of use // New technologies for solid fuel combustion: their current state and future use: 
Proceedings of the All-Russian. scientific and technical seminar. M .: VTI, 2001.S. 286-295.

12. Stennikov V.A., Penkovsky A.V., Postnikov I.V., Edeleva O.A., Mednikova E.E., Dobrovolskaya T.V., Sokolov P.A. Scientific and methodological support of the optimal development of heat supply and its practical implementation in the Irkutsk region // Bulletin of the Irkutsk State Technical University. 2019. No. 4. P.751-763. 